\title{
Old wine, new bottles: In search of dialectics
}

\author{
Forrest Hylton
}

Published online: 3 September 2011

(C) Springer Science+Business Media B.V. 2011

More than 5 years before events in Egypt, Tunisia, and the Arab Spring of 2011 brought revolution back to the forefront of political debate, a national-popular revolution with an indigenous face brought the government of Evo Morales and MAS (Movement for Socialism) to power in Bolivia, in December 2005. Yet the Morales government presents the familiar paradox, dear to historians, of change within continuity. It also speaks to the tensions between culture and political economy, both in the world at large and in academic analyses of it.

Until recently (mid-2011), Morales and MAS enjoyed a level of popularity and legitimacy not seen in Bolivia since the early years of the MNR (Revolutionary Nationalist Movement), following the Revolution of '52. Regionally, Morales's Bolivia has enjoyed better relations with neighboring Chile, Argentina, and Brazil than any regime since General Bánzer's, during the darkest night of Plan Condor. As it has broken off relations with the US government with minimal negative consequences internationally and demonstrably positive consequences internally (in terms of regime consolidation), the Morales administration has carved out a role for itself as the representative of indigenous voices in the global arena. Therefore it has also taken the lead on issues related to climate change and coca production.

Some of the known facts are worth restating in order to grasp the magnitude of the changes in official politics that followed the revolutionary cycle of 2000-2005: elected with $54 \%$ of the vote on an $85 \%$ turnout in 2005 , in 2009 , Morales was reelected with $60 \%$ of the vote on a turnout of $90 \%$. In 2005, MAS won a bare majority in the Chamber of Deputies (65 out of 130), and 12 of 27 Senate seats, but in 2009, MAS took 25 of 36 Senate seats and 82 of 130 seats in the Chamber of Deputies. After taking 33\% in Santa Cruz in 2005, Morales took $41 \%$ of votes in the heartland of rightwing reaction in 2009. In the other departments of the rightwing media luna (the "half moon" refers to the four easterly departments that shape the

\footnotetext{
F. Hylton $(\bowtie)$

Departamento de Historia, Universidad de los Andes, Bogota, Colombia

e-mail: ht.forrest20@uniandes.edu.co
} 
geographic opposition to Morales's nationalization and redistribution agenda) Beni and Pando-Morales made similar gains relative to 2005, and in Tarija, he took the majority of votes. The weakness of MAS has been in regional rather than national elections, as the opposition took six of nine governorships in 2005, further reflecting the fact that MAS's base lies in the Andean highland departments of Oruro, Potosí, and La Paz. But in 2010, MAS won six governorships, losing by just $5 \%$ in Tarija and 3\% in Beni.

By 2010, MAS had begun to wrest control of the political strongholds of its wealthy and powerful opponents. Not even the MNR had shown such aptitude in the electoral arena. In this sense, the success of Morales and MAS is without historical precedent in modern Bolivian history. The same may be said for Morales and MAS on the world stage: few Left-leaning presidents have disarmed potential criticism more effectively. Unlike Hugo Chávez, Morales has been subject to no barrage of international criticism from liberals and the Left; the right has been even more ineffectual abroad than domestically. If anything, internationally Morales has suffered from an excess of uncritical adulation, based on his humble origins, personal charisma, and indigenous ethnicity. To be sure, no previous Bolivian president had experienced anything similar.

However, despite changes the regime seeks to represent, there are clear continuities in political culture as well as political economy, and in many ways, the new order looks increasingly like the old, at least at the level of practice. To a considerable degree, this explains both the strength and weakness of the Morales government. The continuity of political party clientelism and extractive, exportoriented development is the most remarkable feature of the new order-the liberal capitalist model, albeit one slightly modified in favor of national development, has survived. By Bolivian standards, it could even be said to be thriving.

Of course, the means - clientelismo and caudillismo (patronage and authoritarianism) - undercut the stated ends of government, namely the decolonization of the state and a reorientation of the economy in more ecologically sustainable and socially just direction. In fact, one is left wondering if the goals are other than those stated publicly, since it is difficult to conceive of any government channeling revolutionary dynamism into reformist sclerosis more effectively than the Bolivian government's enthusiasm for mining and resource extraction. Egypt may provide another example, but it is unlikely to produce an Evo Morales, capable of riding the tiger to state power through repeated and resounding electoral triumph.

By way of hypothesis, and at the risk of being schematic, we might say that political dynamics in Bolivia represent something like the reverse of those at work in Venezuela. Though Chávez came to power with strong popular support, in the aftermath of the Caracazo in 1989 and the failed golpe of 1992, the limits of popular movement's strength were evident: other groups, the middle class in particular, were decisive in bringing Chávez to power. It was Chávez's presidency, and above all the frustrated coup of 2002, that empowered popular movements, which became increasingly dynamic and politicized in the following years of rightwing reaction. The mobilization of chavistas, and their participation in the design and implementation of government programs, was key to the defeat of the Venezuelan right in the period leading up to Evo Morales's election, in 2005. 
In Bolivia, before Morales came to power, led by indigenous movements of workers and peasants, popular forces destroyed the remaining legitimacy of the neoliberal party system and sought to redesign both the Bolivian state and its political economy. Evo Morales's electoral victory was the result of the revolutionary cycle of 2000-2005. Morales however, as opposed to Chávez, feared that mobilizing his base would antagonize his rightwing opponents, whom he sought to keep within the fold of official politics. When Morales entered office, the lowland right in Santa Cruz, Beni, Pando, and Tarija was weak, divided, and disorganized. Had Morales pressed his political weight to full advantage by mobilizing the movements that brought him to power, he might have had the field to himself, much as Chávez has.

Instead, unlike indigenous movements demanding non-liberal, territorially based forms of political representation, by threatening sabotage and secession, the lowland right was able to dictate the irregular political rhythm of the Constitutional Assembly, taking the wind out of insurgent sails. Furthermore, between the time the Assembly was designed and concluded, the government showed its reluctance to rely on direct action from below and its willingness to make backroom concessions to the right. As the massacre in Pando-the circumstances of which remain murky-demonstrated, in September 2008, such caution did not restrain the racist violence of the right, or prevent bloodshed, although the rightwing rampage may well have hastened the failed coup plot of October 2008, and the popular ratification of the new Constitution in January 2009.

Ironically, then, on the heels of repeated national-popular victories over the lowland right from 2003 to 2005, and from 2006 to 2008, the Morales government gave the right an opening through which it reconstituted itself as the arbiter of the limits of social change. Whether the issue is natural resources, education and literacy, infrastructural development, or agrarian reform, the MNR reforms at midcentury were more radical and far-reaching than anything MAS has accomplished in the twenty-first. This is because new forms of popular power were institutionalized under the MNR — exemplified in the miners' and peasants' militias-to back up the reforms. MAS, in contrast, has been content to use the rhetoric of indigenous liberation while stopping well short of any major transformations in the political economy.

High growth rates - a result of (a) renegotiation of mining and hydrocarbon contracts in 2006, and (b) high prices for minerals and hydrocarbons-undergirded limited social spending during Morales's first term, in which GDP averaged $4.8 \%$. Though social spending increased in absolute terms, as a percentage of government spending it decreased. Cultural concessions to indigenous movements may have been integral to the maintenance of fiscal austerity in a period in which foreign reserves reached record levels, and in which economic policymakers nevertheless focused on reducing inflation with budget surpluses.

Compared to Argentina and Brazil, which achieved significant reductions in absolute poverty and inequality during the same period, Bolivia's achievements were modest: between 2005 and 2009 , poverty fell by 2.3 percent (3.8 percent in rural areas), and extreme poverty by 6.3 percent (10.2 percent in rural areas). This left the overwhelming majority of Bolivians, especially in the countryside, 
in poverty. The global crisis of capitalism, which arrived in Bolivia after a robust $6.1 \%$ growth rate in 2008, forced the government to enact a stimulus package, which helped Bolivia maintain the highest projected growth rate in the region in 2009.

In terms of its relationships with labor, the government favored business unionism as opposed to co-gobierno or workers' control, and its nationalization of mines in Vinto and Huanuni merely ratified what workers had accomplished on their own, much as the MNR had done with agrarian reform in 1953. Nevertheless, unlike the MNR, the MAS has left the bulk of the mining sector in the hands of transnational mining companies (Japanese, Korean, American, Swiss, and Canadian), and the state sector's percentage of GDP, at $32 \%$, with a projected ceiling of $36 \%$, remains significantly lower than state participation under the MNR.

The main response of Morales and the MAS to social protest and strikes, increasingly visible since 2009 , has been to label mobilized workers and peasants counter-revolutionary. Indeed, cooperative miners, arguably the most reactionary of popular sectors, caused the MAS government great embarrassment when they attacked miners in the state sector without fear of reprisal from their ally, the Minister of Mines, whose appointment was a quid pro quo for electoral support from the cooperative sector. Morales fired the minister, apologized for the mistake, and nationalized Huanuni under great pressure from the FSTMB.

When more than ten thousand anti-capitalist climate change activists descended on Cochabamba in April 2010 at the invitation of the Bolivian government, indigenous peasants and miners continued to battle a Japanese mining company at San Cristóbal without government support. Once the international activists had gone home, largely oblivious to the miners' strike at San Cristóbal and the dissidence expressed at Mesa 18, in May 2010, miners, teachers, health care workers, and factory workers struck in rejection of a proposed 5\% wage increase that would allegedly have afforded them the "good life." Morales and Vice President Álvaro García Linera labeled them counter-revolutionary, and García Linera speculated that the strike was backed by the United States and the lowland right, just as earlier de-stabilization campaigns had been. In August 2010, the general strike in Potosí shut the city down for 2 weeks. Potosí played an important if little commented on role in the revolutionary cycle of 2000-2005, and Morales took $80 \%$ of the vote there in 2009. The protest was not against radical change, but rather lack thereof.

Before his official inauguration as president, Evo Morales was inaugurated with great fanfare at Tiwanaku in January 2006 by indigenous peasants and workers who helped bring him to power, and Morales promised to rule by obeying, asking his base to remain mobilized in order to hold him accountable and to help him correct his inevitable errors. This signaled a willingness to govern in dialogue with social movements and by strengthening those movements - an approach that would have radically recast relations between state and society.

Yet Morales and MAS have ruled over movements and have attempted to substitute for them and, when necessary, to confine their mobilization within the tightest of officially sanctioned channels. Official rhetoric about "communitarian socialism," "accelerating the transition to socialism," and the like, used during and after the 2009 presidential campaign, is just that: rhetoric. Clientelismo and 
caudillismo continue to hold sway in political culture, even if the faces and parties of official politics have changed. The new political economy fits comfortably within the realm of liberal capitalism. Income and wealth are still intensely concentrated and are likely to remain so in the near future.

Nor should we expect the Bolivian state, under Evo Morales or anyone else, to bridge the gap between rhetoric and reality or between culture and political economy. If that happens, it will likely be the work of the movements themselves. As ever, collective action offers indigenous and urban popular sectors the best opportunity to demonstrate their power and, in the process, to make their demands heard. It may also provide the best guarantee that professional observers in history and the social sciences cease to perceive, interpret and project reality, as the state has, although that remains to be seen. 